\title{
CONTRIBUTIONS TO THE CHEMICAL MODELING OF SOME GRANITIC MASSES IN THE CENTRAL EASTERN DESERT, EGYPT
}

\section{ANAS M. EL-SHERIF}

Nuclear Materials Authority, P. O. Box 530, El-Maadi, Cairo, Egypt

\section{ABSTRACT}

Gabal Delihimmi (140 km²), Gabal Abu Tiyur $\left(30 \mathrm{~km}^{2}\right)$ and Gabal Um Shaddad $\left(17 \mathrm{~km}^{2}\right)$ are three granitic masses located in the central Eastern Desert of Egypt, intruding older metavolcanics, granodiorite and metasediments. These three granitic masses were studied geochemically for petrogenetic modeling.

The modal mineralogic analysis shows that Gabal Delihimmi granites are composed of orthoclase perthites, quartz, plagioclase and biotites, whereas Gabal Abu Tiyur and Gabal Um Shaddad granites are composed of microcline perthites, quartz, plagioclase and minor biotites.

Fractional crystallization and mass balance modeling for the younger granites of Gabal Delihimmi granite, Gabal Um Shaddad granite and Gabal Abu Tiyur indicate their derivation from the parent mafic magma granodiorite, through fractional crystallization of plagioclase, hornblende, orthoclase, biotite, quartz and apatite with residual liquid ranging from $0.00 \%$ to $0.13 \%$. The relatively small value $\sum R 2(0.001)$ indicates a good fit of the resulting model.

Using REE petrogenetic modeling, Gabal Delihimmi granite can be produced from 40\% non-modal partial melting for the bulk continental source materials followed by 35\% crystal fractionation whereas Gabal Abu Tiyur (type 1) and Gabal Um Shaddad granites can be produced from 30\% non-modal partial melting for the upper continental source materials followed by $40 \%$ crystal fractionation. On the other hand, Gabal Abu Tiyur granite (type 2) can be produced from granitic source materials by $50 \%$ modal partial melting followed by $60 \%$ crystal fractionation.

The tetrad effect was a feature of the magma-fluid system before magmatic crystallization or that the tetrad effect in the whole rock samples was inherited from an external fluid during or after the emplacement of the magma.

\section{INTRODUCTION}

The Egyptian basement rocks comprise a wide variety of gneisses, dismembered ophiolites, island arc metavolcanics, metasediments, metagabbros and unmetamorphosed volcanics, and extensively intruded by various types of granitoid plutons (El-Gaby et al., 1988; Hassan and Hashad, 1990). The Egyptian granitoids were classified according to their color into gray, red and pink; to their type locality into Shaitian and Gattarian; to their relative age into older and younger, to their relation to orogeny into syn-, late- and post-orogenic; and to their tectonic setting into subduction-related (G1), suture and crustal thickening (G2) and intraplate anorogenic (G3) (Hussein et al., 1982).

The studied areas were extensively studied by Sabet (1961), Ries et al. (1983), El-Alfy (1992), Ragab et al., (1993), Hamimi (1996), Khudeir et al., (1995), Mohamed (2001), Mohamed et al., (2001), Abd El-Wahed et al., (2002), El-Husseiny (2003) and Abd El-Wahed et al., (2004).

Rare earth elements modeling calculations have been used successfully in the study of the petrogenesis and origin of basaltic rocks which may have been derived by partial melting of upper mantle source materials and modified by differentiation or reaction with the crust. On the other hand, granitic rocks may have been derived by partial melting of the mantle, or the subducted oceanic crust or lower continental crust. The melt may be modified by differentiation, mixing with other melts, or reaction with crustal rocks of various compositions during its ascent over a wide range of $\mathrm{P}, \mathrm{T}$ and $\mathrm{pH}$ conditions.

The present study deals mainly with the chemical modeling of Gabal Delihimmi, Gabal Um Shaddad and Gabal Abu Tiyur granitic masses located in the Central Eastern Desert of Egypt.

\section{GEOLOGIC SETTING}

The studied granites are located between Longitudes $34^{\circ} 07^{\prime}$ and $34^{\circ} 26^{\prime} \mathrm{E}$ and Latitudes $25^{\circ} 36^{\prime}$ and $25^{\circ} 49^{\prime} \mathrm{N}$. Gabal Delihimmi granite represents an oval-shaped pluton that covers about $140 \mathrm{~km}^{2}$ (Fig.1) and exhibits low to moderate relief (528 m.a.s.1.). This granite exhibits exfoliation and spheroidal weathering. It enclos- 
es a large number of granodioritic xenoliths near the contact. It is highly jointed with close spacing and cut by dyke swarms. The pluton shows sharp intrusive contacts with the older country rocks as serpentinites, metagabbros, metavolcanics and metasediments.

Gabal Abu Tiyur granite is an elongated pluton, located in the western part of the study area and covering about $30 \mathrm{~km}^{2}$. It shows high relief (1099 m.a.s.1.) and composed of medium to coarse grained granitic rocks. The contacts with the metavolcanics and metasediments are sharp. The pluton exhibits exfoliation weathering.

Gabal Um Shaddad granite is pink to red colour (775 m.a.s.1.), located in the southern part of the study area covering about $17 \mathrm{~km}^{2}$ and forming an irregular intrusion. It intrudes the surrounding metasediments with sharp intrusive contacts.

\section{MODAL ANALYSIS CHARACTERISTICS}

Gabal Delihimmi granite is medium-, to coarse-grained rocks composed essentially of quartz ( $\sim 2 \%)$, K-feldspars ( $\sim 35 \%)$, plagioclase $(\sim 15 \%)$, biotite $(\sim 6 \%)$ as well as accessories $(\sim 0.8 \%)$, while Gabal Abu Tiyur granite is medium to coarse grained and composed mainly of K-feldspars $(\sim 63 \%)$, quartz $(\sim 33 \%)$, plagio- clase $(\sim 2 \%)$ with minor biotite $(\sim 1 \%)$. Zircon and opaques represent the accessory minerals ( $\sim 0.4 \%)$. Gabal Um Shaddad granite is medium to coarse grained and consists mainly of $\mathrm{K}$ feldspar ( $\sim 56 \%)$, quartz $(\sim 37 \%)$ and plagioclase $(\sim 3 \%)$ with minor biotite $(\sim 1 \%)$. Accessories $(\sim 1 \%)$ are zircon and opaques $(\sim 1.5 \%)$. It displays equigranular texture with quartz and perthite phenocrysts.

\section{GEOCHEMISTRY}

The geochemistry of the studied area is focused mainly on the granodiorite and the younger granite of Gabal Delihimmi, Gabal Abu Tiyur and Gabal Um Shaddad masses to clarify their geochemical characteristics and genetic relations. The analyses Data of the analyzed samples are from Mohamed, (2001) that were carried out by the wet chemistry method in NMA Laboratories, (Table 1) and Abdel Wahid et al., (2004), that were carried out by the ICP-MS in the ACME Labs., Vancouver, Canada, (Table 2).

\section{FRACTIONATION MODELLING}

Mass balance has been an important tool for petrological and geochemical studies, such as mineral reactions, trace element distribution, fusion, crystallization and mixing (Albaréde, 1995). GLG-Modes program is one of the mass

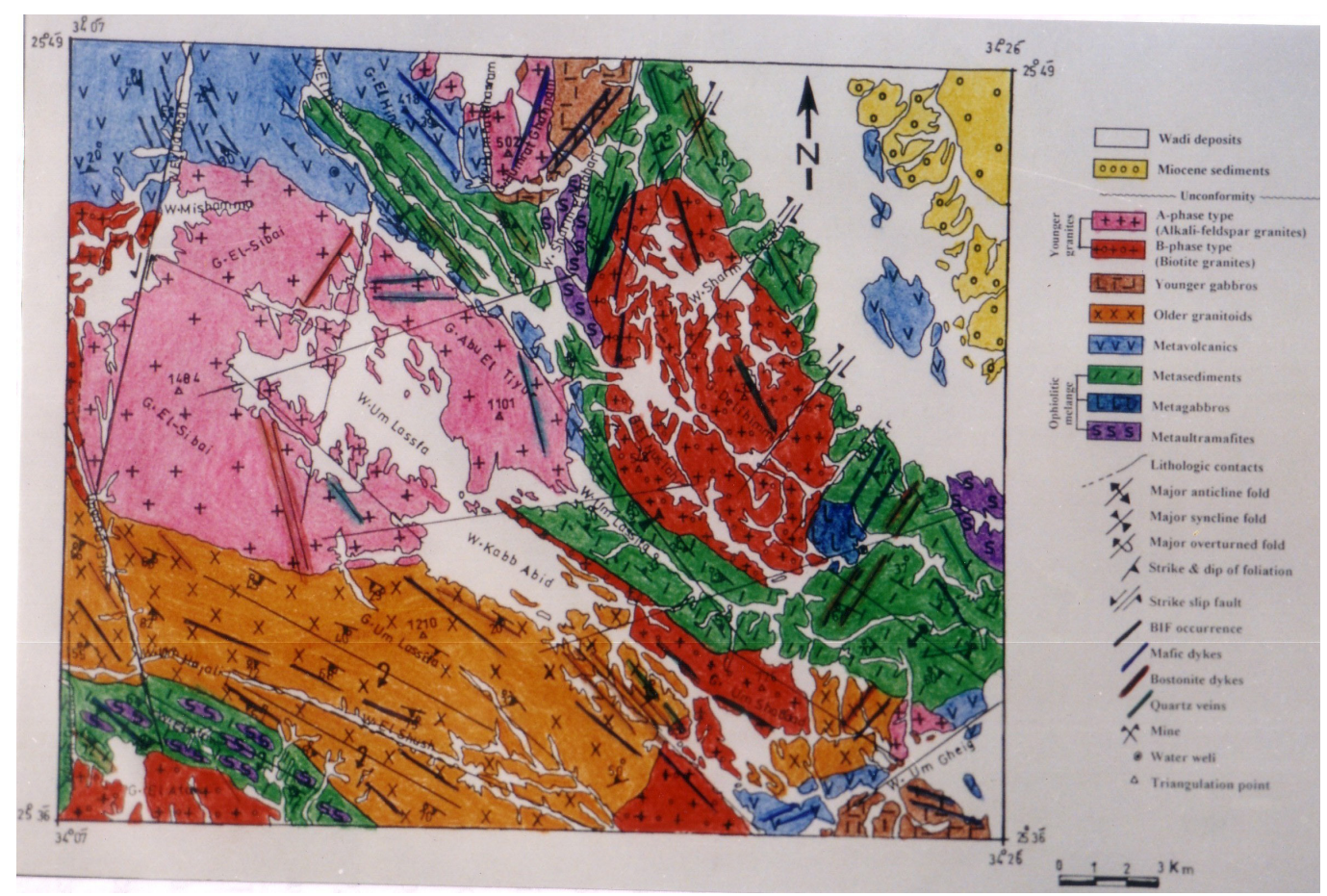

Fig. (1): Geological map of the studied granitic masses (Mohamed, 2001) 
CONTRIBUTIONS TO THE CHEMICAL MODELING

Table (1): Major oxides (Wt \%) of the studied granodiorites, (Mohamed, 2001).

\begin{tabular}{|c|ccccccccc|}
\hline S. No. & 63 & 65 & 93 & 94 & 95 & 108 & 112 & 113 & 168 \\
\hline $\mathrm{SiO}_{2}$ & 69.12 & 67.63 & 58.70 & 67.10 & 65.32 & 68.75 & 66.85 & 67.53 & 68.10 \\
$\mathrm{TiO}_{2}$ & 00.51 & 00.49 & 00.61 & 00.58 & 00.60 & 00.47 & 00.52 & 00.49 & 00.50 \\
$\mathrm{Al}_{2} \mathrm{O}_{3}$ & 14.85 & 15.11 & 15.02 & 14.15 & 16.21 & 14.63 & 15.50 & 14.85 & 15.24 \\
$\mathrm{Fe}_{2} \mathrm{O}_{3}$ & 1.44 & 1.96 & 3.30 & 2.34 & 1.75 & 1.60 & 1.01 & 1.68 & 1.41 \\
$\mathrm{FeO}$ & 1.97 & 1.80 & 4.66 & 2.40 & 2.39 & 1.80 & 2.79 & 1.96 & 1.94 \\
$\mathrm{MnO}$ & 00.07 & 00.06 & 0.14 & 00.11 & 00.09 & 00.09 & 00.08 & 00.10 & 00.05 \\
$\mathrm{MgO}$ & 1.03 & 1.12 & 2.86 & 2.10 & 1.8 & 1.42 & 1.07 & 00.99 & 1.03 \\
$\mathrm{CaO}$ & 3.80 & 4.47 & 6.48 & 4.92 & 4.42 & 4.41 & 4.18 & 3.82 & 4.05 \\
$\mathrm{Na}_{2} \mathrm{O}$ & 2.95 & 2.93 & 2.79 & 2.70 & 2.66 & 3.18 & 2.82 & 2.98 & 2.92 \\
$\mathrm{~K}_{2} \mathrm{O}$ & 2.74 & 2.65 & 2.18 & 2.06 & 2.04 & 1.90 & 2.56 & 2.74 & 2.17 \\
$\mathrm{P}_{2} \mathrm{O}_{5}$ & 00.25 & 00.26 & 0.36 & 00.37 & 00.39 & 0.25 & 00.33 & 00.28 & 00.28 \\
$\mathrm{LOI}$ & 1.03 & 1.46 & 2.74 & 1.14 & 1.90 & 1.38 & 2.21 & 2.50 & 1.89 \\
$\mathrm{Total}$ & 99.76 & 99.94 & 99.84 & 99.97 & 99.70 & 99.88 & 99.92 & 99.87 & 99.79 \\
\hline
\end{tabular}

balance calculation programs, designed to calculate the proportions of mineral phases present in a rock from chemical analyses of the rock and the constituent minerals. The program solves linear least-squares mass-balance equations of Wright and Doherty (1970), makes calculations and can trace the composition of derivative magmas as phases are added or subtracted from an initial magma. The principles of the calculation consider a set of geochemical analyses of representative whole rock samples (e.g. From volcanic, granite...), which are to be tested for the validity of fractional crystallization (FC) processes for their evolution.

The rock with the lowest $\mathrm{SiO}_{2}$ content can be assumed to be the parent rock (PR) of a sample with a highest $\mathrm{SiO}_{2}$ content (the daughter rock, DR). To test this hypothesis a mass balance calculation could be performed, knowing the compositions of the parent and the daughter rocks and their respective modal minerals. The compositions of the fractioned phases are chosen from Dear et al., (1966) with the guidance of the normative studies. The method tries to minimize sum square of the residuals $\left(\sum \mathrm{R}^{2}\right)$. The small value of the $\left(\sum \mathrm{R}^{2}\right)$ indicates a good fit of the resulting model. The calculation has been performed for granodiorite and the younger granite of Gabal Delihimmi as one system, then granodiorite and the younger granite of Gabal Um Shaddad as another separate system and finally granodiorite and the younger granite of Gabal Abu Tiyur as one system.
Within the granodiorite and younger granite of Gabal Delihimmi system Table (3), the observed daughter or the most compositionally evolved younger granite sample (S. No.1 and Table 2) can be derived from the most mafic magma of the observed parent granodiorite sample (S. No.93 Table 1) by fractional crystallization of plagioclase $37.78 \%$, hornblende $27.74 \%$, orthoclase $5.86 \%$, biotite $9.40 \%$, quartz $19.07 \%$ and apatite $0.25 \%$ with $0.00 \%$ residual liquid sample (S. No.1). The relatively small value $\sum \mathrm{R}^{2}(0.001)$ indicates a good fit of the resulting model.

Within the granodiorite and younger granite of Gabal Um Shaddad system Table (4), the observed daughter or the most compositionally evolved younger granite sample (S. No. 12 and Table 2) can be derived from the most mafic magma of the observed parent granodiorite sample (S. No.93 and Table 1) by fractional crystallization of plagioclase $38.71 \%$, hornblende $27.65 \%$, orthoclase $5.07 \%$, biotite $9.34 \%$, quartz $18.84 \%$ and apatite $0.26 \%$ with $0.13 \%$ residual liquid sample (S. No.12). The relatively small value $\sum \mathrm{R}^{2}(0.001)$ indicates a good fit of the resulting model.

Within the granodiorite and younger granite of Gabal Abu Tiyur system Table (5), the observed daughter or the most compositionally evolved younger granite sample (S. No.18 and Table 2) can be derived from the most mafic magma of the observed parent granodiorite sample (S. No.93 and Table 1) by fractional crystalliza- 
Table (2): Major oxides (wt\%), trace and rare earth elements (ppm) of the studied younger granites, (Abdel Wahid et al., 2004).

\begin{tabular}{|c|c|c|c|c|c|c|c|c|c|c|c|c|}
\hline \multirow[t]{2}{*}{ S. No. } & \multicolumn{11}{|c|}{ Gabal Delihimmi granite } & \multirow{2}{*}{$\begin{array}{c}\text { Ave.Del } \\
\mathbf{N}=11\end{array}$} \\
\hline & 1 & 2 & 3 & 4 & 5 & 6 & 7 & 8 & 9 & 10 & 11 & \\
\hline $\mathrm{SiO}_{2}$ & 74.51 & 74.20 & 73.85 & 73.79 & 72.11 & 74.46 & 74.38 & 74.17 & 74.01 & 73.83 & 73.55 & 74.34 \\
\hline $\mathrm{TiO}_{2}$ & 0.21 & 0.27 & 0.27 & 0.26 & 0.26 & 0.21 & 0.23 & 0.21 & 0.23 & 0.23 & 0.24 & 0.21 \\
\hline $\mathrm{Al}_{2} \mathrm{O}_{3}$ & 12.98 & 12.74 & 13.17 & 13.05 & 14.01 & 12.98 & 12.90 & 12.93 & 13.04 & 12.64 & 12.96 & 12.97 \\
\hline $\mathrm{Fe}_{2} \mathrm{O}_{3}{ }^{\mathrm{t}}$ & 1.92 & 2.45 & 2.17 & 2.56 & 2.35 & 2.10 & 2.34 & 2.12 & 2.39 & 2.33 & 2.50 & 2.12 \\
\hline MnO & 0.05 & 0.04 & 0.04 & 0.05 & 0.05 & 0.03 & 0.04 & 0.04 & 0.04 & 0.04 & 0.04 & 0.04 \\
\hline MgO & 0.42 & 0.43 & 0.44 & 0.36 & 0.53 & 0.29 & 0.28 & 0.25 & 0.29 & 0.28 & 0.30 & 0.31 \\
\hline $\mathrm{CaO}$ & 1.36 & 1.20 & 1.63 & 1.21 & 1.74 & 0.98 & 1.58 & 1.26 & 1.32 & 1.23 & 1.34 & 1.21 \\
\hline $\mathrm{Na}_{2} \mathrm{O}$ & 3.71 & 3.44 & 3.70 & 3.73 & 4.10 & 3.51 & 3.89 & 3.43 & 3.61 & 3.68 & 3.60 & 3.71 \\
\hline $\mathbf{K}_{2} \mathbf{O}$ & 3.95 & 3.79 & 3.94 & 3.53 & 3.54 & 4.46 & 3.41 & 4.64 & 4.31 & 4.52 & 4.44 & 4.04 \\
\hline $\mathrm{P}_{2} \mathrm{O}_{5}$ & 0.05 & 0.08 & 0.07 & 0.05 & 0.06 & 0.07 & 0.03 & 0.03 & 0.06 & 0.05 & 0.05 & 0.05 \\
\hline L.O.I. & 0.80 & 0.80 & 0.70 & 1.00 & 1.00 & 0.70 & 0.80 & 0.70 & 0.50 & 1.20 & 0.90 & 0.84 \\
\hline Total & 100.00 & 99.51 & 100.04 & 99.71 & 99.83 & 99.87 & 99.95 & 99.85 & 99.85 & 100.10 & 99.99 & \\
\hline \multicolumn{13}{|c|}{ Trace Elements (ppm) } \\
\hline $\mathbf{N b}$ & 13.20 & 10.60 & 15.30 & 15.50 & 14.50 & 11.30 & 11.90 & 11.10 & 11.80 & 11.10 & 12.80 & 13.10 \\
\hline $\mathbf{R b}$ & 146.70 & 81.40 & 137.90 & 67.00 & 150.50 & 93.00 & 73.90 & 89.50 & 88.10 & 89.20 & 90.90 & 116.30 \\
\hline $\mathrm{Sr}$ & 92.90 & 121.60 & 115.70 & 127.50 & 95.50 & 95.10 & 113.10 & 105.40 & 102.70 & 102.90 & 113.60 & 93.90 \\
\hline $\mathbf{Z r}$ & 135.00 & 177.60 & 135.50 & 222.10 & 126.70 & 208.30 & 223.50 & 190.90 & 222.40 & 208.50 & 201.00 & 175.50 \\
\hline Ba & 324.00 & 526.00 & 424.00 & 953.00 & 299.00 & 696.00 & 465.00 & 583.00 & 560.00 & $\mathbf{5 7 8 . 0 0}$ & 540.00 & 474.15 \\
\hline $\mathbf{Y}$ & 25.00 & 22.20 & 43.60 & 34.70 & 36.90 & 28.80 & 31.60 & 30.30 & 30.00 & 30.10 & 33.30 & 32.12 \\
\hline \multicolumn{13}{|c|}{ REE (ppm) } \\
\hline La & 23.50 & 31.10 & 24.60 & 32.40 & 17.40 & 61.90 & 42.80 & 47.70 & 51.60 & 45.10 & 73.70 & 41.07 \\
\hline $\mathrm{Ce}$ & 45.00 & 86.40 & 55.30 & 67.40 & 39.70 & 127.20 & 90.90 & 101.30 & 106.50 & 96.30 & 155.00 & 88.30 \\
\hline Pr & 5.84 & $\begin{array}{l}7.35 \\
7.35\end{array}$ & 6.20 & 7.51 & 4.42 & 13.21 & 9.87 & 10.72 & 11.56 & 10.56 & 16.92 & 9.50 \\
\hline Nd & 22.80 & 27.80 & 24.80 & 28.50 & 17.90 & 47.60 & 37.70 & 39.30 & 42.30 & 39.40 & 60.50 & 35.30 \\
\hline Sm & 5.20 & 5.10 & 6.00 & 6.40 & 4.70 & 8.00 & 7.00 & 7.20 & 7.60 & 7.60 & 10.20 & 6.82 \\
\hline Eu & 0.66 & 1.03 & 0.69 & 1.57 & 0.62 & 1.33 & 1.39 & 1.35 & 1.28 & 1.23 & 1.44 & 1.15 \\
\hline Gd & 5.19 & 4.25 & 5.98 & 5.70 & 4.95 & 5.50 & 5.74 & 5.49 & 5.73 & 5.61 & 6.81 & 5.50 \\
\hline Tb & 0.87 & 0.66 & 1.06 & 0.94 & 0.82 & 0.85 & 0.91 & 0.87 & 0.88 & 0.87 & 1.09 & 0.90 \\
\hline Dy & 6.00 & 4.24 & 7.29 & 6.07 & 5.75 & 5.38 & 5.92 & 5.69 & 5.80 & 5.82 & 6.74 & 5.90 \\
\hline Ho & 1.24 & 0.79 & 0.41 & 1.21 & 1.18 & 0.96 & 1.09 & 1.05 & 1.06 & 1.04 & 1.18 & 1.02 \\
\hline Er & 4.06 & 2.57 & 4.48 & 3.73 & 3.85 & 3.09 & 3.34 & 3.24 & 3.24 & 3.25 & 3.69 & 3.50 \\
\hline Tm & 0.59 & 0.34 & 0.65 & 0.51 & 0.55 & 0.39 & 0.43 & 0.41 & 0.41 & 0.42 & 0.45 & 0.47 \\
\hline $\mathbf{Y b}$ & 4.54 & 2.57 & 4.88 & 3.79 & 4.18 & 2.97 & 3.22 & 3.09 & 3.12 & 3.10 & 3.28 & 3.50 \\
\hline Lu & 0.73 & 0.40 & 0.75 & 0.60 & 0.69 & 0.44 & 0.48 & 0.47 & 0.48 & 0.49 & 0.49 & 0.60 \\
\hline
\end{tabular}

Note: Total iron as $\mathrm{Fe}_{2} \mathrm{O}_{3}=\mathrm{Fe}_{2} \mathrm{O}_{3}$

Table (2, cont.): Major oxides(wt\%), trace and rare earth elements (ppm) of the studied younger granites, (Abdel Wahid et al., 2004).

\begin{tabular}{|c|c|c|c|c|c|c|c|c|c|c|c|c|c|c|c|c|c|}
\hline \multirow{2}{*}{ S.No. } & \multicolumn{6}{|c|}{ Gabal Um Shaddad granite } & \multirow{2}{*}{$\underset{\mathbf{N}=\mathbf{6}}{\text { Av. Shad }}$} & \multicolumn{9}{|c|}{ Gabal Abu Tiyur granite } & \multirow{2}{*}{$\begin{array}{l}\text { Av2 } \\
N=5\end{array}$} \\
\hline & 12 & 13 & 14 & 15 & 16 & 17 & & 18 & 19 & 20 & $\begin{array}{l}\text { Av1 } \\
\text { N=3 }\end{array}$ & 21 & 22 & 23 & 24 & 25 & \\
\hline $\mathrm{SiO}_{2}$ & 77.47 & 77.44 & 77.31 & 77.14 & 77.12 & 75.77 & 77.04 & 78.69 & 78.31 & 76.69 & 77.90 & 77.90 & 77.58 & 77.08 & 76.63 & 75.97 & 77.03 \\
\hline $\mathrm{TiO}_{2}$ & 0.17 & 0.17 & 0.14 & 0.14 & 0.10 & 0.15 & 0.15 & 0.13 & 0.17 & 0.19 & 0.16 & 0.06 & 0.07 & 0.07 & 0.08 & 0.08 & 0.07 \\
\hline $\mathrm{Al}_{2} \mathrm{O}_{3}$ & 11.24 & 11.26 & 11.52 & 11.76 & 11.31 & 11.68 & 11.46 & 10.66 & 10.49 & 11.39 & 10.85 & 11.46 & 11.78 & 11.58 & 11.76 & 12.05 & 11.73 \\
\hline $\mathrm{Fe}_{2} \mathrm{O}_{3}{ }^{\mathrm{t}}$ & 2.68 & 1.90 & 1.85 & 1.67 & 1.99 & 2.13 & 2.04 & 1.78 & 2.54 & 2.45 & 2.26 & 1.25 & 1.26 & 1.42 & 1.66 & 1.43 & 1.40 \\
\hline MnO & 0.01 & 0.03 & 0.02 & 0.02 & 0.02 & 0.03 & 0.02 & 0.01 & 0.02 & 0.02 & 0.02 & 0.01 & 0.01 & 0.01 & 0.03 & 0.01 & 0.01 \\
\hline MgO & 0.04 & 0.02 & 0.05 & 0.04 & 0.02 & 0.04 & 0.04 & 0.03 & 0.09 & 0.04 & 0.05 & 0.03 & 0.03 & 0.01 & 0.02 & 0.05 & 0.03 \\
\hline $\mathrm{CaO}$ & 0.12 & 0.27 & 0.36 & 0.39 & 0.24 & 0.76 & 0.36 & 0.15 & 0.19 & 0.11 & 0.15 & 0.26 & 0.24 & 0.26 & 0.28 & 0.33 & 0.27 \\
\hline $\mathrm{Na}_{2} \mathrm{O}$ & 3.12 & 3.79 & 3.28 & 2.99 & 3.79 & 3.35 & 3.40 & 3.32 & 3.27 & 3.71 & 3.43 & 4.14 & 4.20 & 4.17 & 4.06 & 4.27 & 4.17 \\
\hline $\mathrm{K}_{2} \mathrm{O}$ & 4.72 & 4.66 & 4.59 & 4.85 & 4.11 & 4.54 & 4.58 & 4.35 & 3.88 & 4.28 & 4.17 & 4.20 & 4.33 & 4.02 & 4.12 & 4.41 & 4.22 \\
\hline $\mathbf{P}_{2} \mathrm{O}_{5}$ & 0.01 & 0.01 & 0.04 & 0.03 & 0.06 & 0.04 & 0.03 & 0.02 & 0.01 & 0.05 & 0.03 & 0.04 & 0.02 & 0.01 & 0.16 & 0.01 & 0.05 \\
\hline L.O.I. & 0.30 & 0.30 & 0.40 & 0.60 & 0.60 & 1.00 & 0.50 & 0.50 & 0.40 & 0.40 & 0.43 & 0.50 & 0.10 & 0.50 & 0.60 & 1.00 & 0.54 \\
\hline Total & 99.96 & 99.90 & 99.66 & 99.74 & 99.38 & 99.59 & & 99.76 & 99.48 & 99.50 & 99.58 & 99.86 & 99.63 & 99.13 & 99.42 & 99.63 & 99.53 \\
\hline \multicolumn{18}{|c|}{ Trace Elements (ppm) } \\
\hline Nb & 44.80 & 55.50 & 30.20 & 33.60 & 76.20 & 43.30 & 47.30 & 33.40 & 49.30 & 46.90 & 43.20 & 40.30 & 70.50 & 56.90 & 53.00 & 54.20 & 54.98 \\
\hline $\mathbf{R b}$ & 80.90 & 67.20 & 90.10 & 81.40 & 85.10 & 77.80 & 80.40 & 53.40 & 40.80 & 51.30 & 48.50 & 96.70 & 97.40 & 100.80 & 104.00 & 92.30 & 98.24 \\
\hline $\mathrm{Sr}$ & 46.80 & 9.80 & 52.20 & 55.20 & 6.90 & 48.50 & 36.60 & 21.90 & 18.40 & 22.70 & 21.00 & 6.00 & 3.90 & 7.10 & 4.30 & 8.90 & 6.04 \\
\hline $\mathrm{Zr}$ & 356.40 & 471.90 & 235.10 & 327.40 & 347.70 & 295.80 & 339.10 & 397.20 & 611.40 & 430.30 & 479.63 & 294.20 & 267.30 & 321.70 & 262.20 & 245.50 & 278.18 \\
\hline Ba & 837.00 & 508.00 & 820.00 & 943.00 & 142.00 & 778.00 & 671.30 & 946.00 & 960.00 & 1376.00 & 1094.00 & 26.00 & 30.00 & 21.00 & 32.00 & 30.00 & 27.80 \\
\hline $\mathbf{Y}$ & 95.50 & 486.70 & 132.90 & 50.80 & 126.50 & 71.60 & 160.70 & 56.70 & 72.90 & 98.50 & 76.03 & 86.90 & 105.20 & 108.90 & 127.50 & 107.10 & 107.12 \\
\hline \multicolumn{18}{|c|}{ REE (ppm) } \\
\hline La & 100.90 & & 133.00 & 88.80 & 45.40 & 74.70 & 88.56 & 71.20 & 122.40 & 186.70 & 126.77 & 26.00 & 28.70 & 30.70 & 30.40 & 47.20 & 32.60 \\
\hline $\mathrm{Ce}$ & 177.20 & & 156.50 & 197.30 & 121.70 & 172.20 & 165.00 & 162.60 & 208.50 & 229.10 & 200.07 & 64.20 & 68.70 & $\mathbf{7 0 . 7 0}$ & 84.20 & 115.70 & 80.70 \\
\hline $\operatorname{Pr}$ & 26.44 & & 32.59 & 22.06 & 16.22 & 19.55 & 23.37 & 19.15 & 32.48 & 42.80 & 31.48 & 8.18 & 10.40 & 10.18 & 10.19 & 15.13 & 10.82 \\
\hline Nd & 102.90 & & 144.10 & 84.60 & 73.40 & 77.20 & 96.24 & 78.70 & 130.00 & 184.60 & 131.10 & 32.10 & 44.70 & 43.50 & 43.90 & 64.30 & 45.70 \\
\hline Sm & 18.20 & & 35.40 & 14.70 & 23.00 & 15.20 & 21.30 & 16.90 & 24.40 & 38.50 & 26.60 & 10.30 & 15.40 & 13.90 & 14.80 & 19.90 & 14.86 \\
\hline Eu & 2.80 & & 6.36 & 2.29 & 2.01 & 2.17 & 3.13 & 2.59 & 3.19 & 7.68 & 4.49 & 0.59 & 0.91 & 0.77 & 0.88 & 1.16 & 0.86 \\
\hline Gd & 14.31 & & 37.01 & 9.58 & 21.70 & 11.27 & 18.77 & 12.50 & 16.05 & 33.11 & 20.55 & 10.90 & 16.19 & 14.35 & 16.79 & 19.18 & 15.48 \\
\hline Tb & 2.57 & & 5.78 & 1.60 & 3.93 & 2.04 & 3.18 & 2.05 & 2.56 & 4.46 & 3.02 & 2.20 & 3.08 & 2.66 & 3.33 & 3.42 & 2.94 \\
\hline Dy & 16.29 & & 32.13 & 10.23 & 25.46 & 13.50 & 19.52 & 12.82 & 15.81 & 25.55 & 18.06 & 15.69 & 20.01 & 18.22 & 23.41 & 21.33 & 19.73 \\
\hline Ho & 3.17 & & 5.45 & 1.84 & 4.92 & 2.54 & 3.58 & 2.27 & 2.65 & 4.03 & 2.98 & 3.15 & 3.92 & 3.58 & 4.53 & 3.83 & 3.80 \\
\hline Er & 10.81 & & 14.32 & 5.83 & 14.29 & 7.85 & 10.62 & 6.84 & 6.13 & 10.47 & 7.81 & 9.95 & 3.58 & 11.43 & 13.34 & 11.02 & 9.86 \\
\hline Tm & 1.43 & & 1.56 & 0.73 & 1.75 & 1.02 & 1.30 & 0.83 & 0.97 & 1.12 & 0.97 & 1.30 & 1.47 & 1.49 & 1.65 & 1.34 & 1.45 \\
\hline $\mathbf{Y b}$ & 8.90 & & 10.37 & 5.44 & 11.38 & 7.54 & 8.73 & 5.94 & 7.24 & 7.91 & 7.03 & 9.12 & 9.85 & 10.67 & 10.66 & 9.11 & 9.88 \\
\hline Lu & 1.27 & & 1.44 & 0.81 & 1.60 & 1.15 & 1.25 & 0.92 & 1.10 & 1.15 & 1.06 & 1.32 & 1.38 & 1.58 & 1.52 & 1.31 & 1.42 \\
\hline
\end{tabular}

Note: Total iron as $\mathrm{Fe}_{2} \mathrm{O}_{3}=\mathrm{Fe}_{2} \mathrm{O}_{3}{ }^{\mathrm{t}}$ 
Table (3): Fractionating modeling and mineral composition used in mass balance calculations (Wright and

Doherty, 1970) for granodiorites and younger granites of Gabal Delihimmi as one system.

\begin{tabular}{|c|c|c|c|c|c|c|c|c|c|c|}
\hline & \multirow{2}{*}{$\begin{array}{l}\text { Observed } \\
\text { daughter } \\
\text { (S. No.1) }\end{array}$} & \multirow{2}{*}{$\begin{array}{l}\text { Observed } \\
\text { Parent } \\
\text { (S. No.93) }\end{array}$} & \multirow{2}{*}{$\begin{array}{c}\text { Calculated } \\
\text { Parent }\end{array}$} & \multirow{2}{*}{$\begin{array}{l}\text { Weighted } \\
\text { residual }\end{array}$} & \multicolumn{6}{|c|}{$\begin{array}{l}\text { Fractionating phases } \\
\text { (Deer et al., 1966) }\end{array}$} \\
\hline & & & & & An37 & $\mathrm{Hb}$. & Ortho. & Biot. & Qz. & Apt. \\
\hline $\mathrm{SiO}_{2}$ & 75.32 & 60.89 & 60.90 & 0.00 & 57.99 & 45.73 & 61.56 & 37.38 & 99.53 & 0.00 \\
\hline $\mathrm{TiO}_{2}$ & 0.21 & 0.63 & 0.61 & 0.03 & 0.00 & 1.51 & 0.00 & 1.87 & 0.00 & 0.00 \\
\hline $\mathrm{Al}_{2} \mathrm{O}_{3}$ & 13.12 & 15.58 & 15.58 & 0.00 & 26.42 & 11.39 & 21.40 & 11.92 & 0.06 & 0.00 \\
\hline $\mathrm{FeO}^{*}$ & 1.81 & 7.91 & 7.92 & -0.01 & 0.19 & 16.46 & 0.00 & 32.59 & 0.09 & 0.22 \\
\hline $\mathrm{MnO}$ & 0.05 & 0.14 & 0.14 & 0.00 & 0.00 & 0.33 & 0.00 & 0.44 & 0.00 & 0.00 \\
\hline $\mathrm{MgO}$ & 0.42 & 2.97 & 2.97 & -0.01 & 0.03 & 10.60 & 0.00 & 0.25 & 0.00 & 0.53 \\
\hline $\mathrm{CaO}$ & 1.37 & 6.72 & 6.72 & 0.00 & 7.83 & 12.33 & 1.51 & 0.16 & 0.00 & 54.84 \\
\hline $\mathrm{Na}_{2} \mathrm{O}$ & 3.75 & 2.89 & 2.89 & 0.00 & 6.47 & 0.99 & 2.39 & 0.39 & 0.00 & 0.21 \\
\hline $\mathrm{K}_{2} \mathrm{O}$ & 3.99 & 2.26 & 2.26 & 0.00 & 1.10 & 0.80 & 12.76 & 8.78 & 0.00 & 0.00 \\
\hline
\end{tabular}

Note that the analyses were recalculated to $100 \%$ and the total iron is given as $\mathrm{FeO}$. The composition of the fractionated phases (An37, Hb., Ortho. Bio, Qz. and Apt.) are from Deer et al., (1966). Residual liquid (sample No. 1) $=\mathbf{0 . 0 0 \%}$, fractionating phases $=\mathbf{1 0 0 . 1 \%}$ (plagioclase $\mathbf{3 7 . 7 8 \%}$, hornblende $27.74 \%$, orthoclase $5.86 \%$, biot. $9.40 \%$, quartz $19.07 \%$ and apatite $0.25 \%$ ). Sum of square of residuals $\left(\sum \mathbf{R} 2\right)$ is $\mathbf{0 . 0 0 1}$.

Table (4): Fractionating modeling and mineral composition used in mass balance calculations (Wright and

Doherty, 1970) for granodiorites and younger granites of Gabal Um Shaddad as one system.

\begin{tabular}{|c|c|c|c|c|c|c|c|c|c|c|}
\hline & \multirow{2}{*}{$\begin{array}{l}\text { Observed } \\
\text { daughter } \\
\text { (S. No.12) }\end{array}$} & \multirow{2}{*}{$\begin{array}{l}\text { Observed } \\
\text { Parent } \\
\text { (S. No.93) }\end{array}$} & \multirow{2}{*}{$\begin{array}{c}\text { Calculated } \\
\text { Parent }\end{array}$} & \multirow{2}{*}{$\begin{array}{c}\text { Weighted } \\
\text { residual }\end{array}$} & \multicolumn{6}{|c|}{$\begin{array}{l}\text { Fractionating phases } \\
\text { (Deer et al. 1966) }\end{array}$} \\
\hline & & & & & An37 & $\mathrm{Hb}$. & Ortho. & Biot. & Qz. & Apt. \\
\hline $\mathrm{SiO}_{2}$ & 78.02 & 60.89 & 60.90 & 0.00 & 57.99 & 45.73 & 63.01 & 37.38 & 99.53 & 0.00 \\
\hline $\mathrm{TiO}_{2}$ & 0.17 & 0.63 & 0.60 & 0.03 & 0.00 & 1.51 & 0.00 & 1.87 & 0.00 & 0.00 \\
\hline $\mathrm{Al}_{2} \mathrm{O}_{3}$ & 11.32 & 15.58 & 15.58 & 0.00 & 26.42 & 11.39 & 19.73 & 11.92 & 0.06 & 0.00 \\
\hline $\mathrm{FeO}^{*}$ & 2.43 & 7.91 & 7.92 & 0.00 & 0.19 & 16.46 & 0.62 & 32.59 & 0.09 & 0.22 \\
\hline $\mathrm{MnO}$ & 0.01 & 0.14 & 0.13 & 0.01 & 0.00 & 0.33 & 0.00 & 0.44 & 0.00 & 0.00 \\
\hline $\mathrm{MgO}$ & 0.04 & 2.97 & 2.98 & -0.01 & 0.03 & 10.60 & 0.19 & 0.25 & 0.00 & 0.53 \\
\hline $\mathrm{CaO}$ & 0.12 & 6.72 & 6.72 & 0.00 & 7.83 & 12.33 & 0.26 & 0.16 & 0.00 & 54.84 \\
\hline $\mathrm{Na}_{2} \mathrm{O}$ & 3.14 & 2.89 & 2.90 & -0.01 & 6.47 & 0.99 & 1.51 & 0.39 & 0.00 & 0.21 \\
\hline $\mathrm{K}_{2} \mathrm{O}$ & 4.75 & 2.26 & 2.26 & 0.00 & 1.10 & 0.80 & 14.53 & 8.78 & 0.00 & 0.00 \\
\hline
\end{tabular}

Note that the analyses were recalculated to $100 \%$ and the total iron is given as $\mathrm{FeO}^{*}$. The composition of the fractionated phases (An37, Hb., Ortho. Bio, Qz. and Apt.) are from Deer et al. (1966). Residual liquid $($ sample No. 1$)=0.13 \%$, fractionating phases $=99.87 \%$ (plagioclase $38.71 \%$, hornblende $27.65 \%$, orthoclase $5.07 \%$, biot. $9.34 \%$, quartz $18.84 \%$ and apatite $0.26 \%$ ). Sum of square of residuals $\left(\sum R^{2}\right)$ is 0.001 .

Table (5): Fractionating modeling and mineral composition used in mass balance calculations (Wright and Doherty, 1970) for granodiorites and younger granites of Gabal Abu Tiyur as one system.

\begin{tabular}{|c|c|c|c|c|c|c|c|c|c|c|}
\hline & \multirow{2}{*}{$\begin{array}{c}\text { Observed } \\
\text { daughter }\end{array}$} & Observed & Parent & \multirow{2}{*}{$\begin{array}{c}\text { Calculated } \\
\text { (S. No.18) }\end{array}$} & Weighted & \multicolumn{6}{|c|}{ Fractionating phases } \\
\cline { 6 - 12 } & (S. No.93) & Parent & residual & An37 & Hb. & Ortho. & Biot. & Qz. & Apt. \\
\hline $\mathrm{SiO} 2$ & 79.53 & 60.89 & 60.90 & 0.00 & 57.99 & 45.73 & 63.01 & 37.38 & 99.53 & 0.00 \\
\hline $\mathrm{TiO} 2$ & 0.13 & 0.63 & 0.60 & 0.03 & 0.00 & 1.51 & 0.00 & 1.87 & 0.00 & 0.00 \\
\hline $\mathrm{Al2O} 3$ & 10.77 & 15.58 & 15.58 & 0.00 & 26.42 & 11.39 & 19.73 & 11.92 & 0.06 & 0.00 \\
\hline $\mathrm{FeO}$ & 1.62 & 7.91 & 7.92 & 0.00 & 0.19 & 16.46 & 0.62 & 32.59 & 0.09 & 0.22 \\
\hline $\mathrm{MnO}$ & 0.01 & 0.14 & 0.13 & 0.01 & 0.00 & 0.33 & 0.00 & 0.44 & 0.00 & 0.00 \\
\hline $\mathrm{MgO}$ & 0.03 & 2.97 & 2.98 & -0.01 & 0.03 & 10.60 & 0.19 & 0.25 & 0.00 & 0.53 \\
\hline $\mathrm{CaO}$ & 0.15 & 6.72 & 6.72 & 0.00 & 7.83 & 12.33 & 0.26 & 0.16 & 0.00 & 54.84 \\
\hline $\mathrm{Na} 2 \mathrm{O}$ & 3.36 & 2.89 & 2.90 & -0.01 & 6.47 & 0.99 & 1.51 & 0.39 & 0.00 & 0.21 \\
\hline $\mathrm{K} 2 \mathrm{O}$ & 4.40 & 2.26 & 2.26 & 0.00 & 1.10 & 0.80 & 14.53 & 8.78 & 0.00 & 0.00 \\
\hline
\end{tabular}

Note that the analyses were recalculated to $100 \%$ and the total iron is given as $\mathrm{FeO}^{*}$. The composition of the fractionated phases (An37, Hb., Ortho. Bio, Qz. and Apt.) are from Deer et al., (1966). Residual liquid (sample No. 1) $=\mathbf{0 . 0 0} \%$, fractionating phases $=\mathbf{9 9 . 9 9 \%}$ (plagioclase $38.74 \%$, hornblende $27.65 \%$, orthoclase $5.10 \%$, biot. $9.34 \%$, quartz $18.90 \%$ and apatite $0.26 \%$ ). Sum of square of residuals $\left(\sum R^{2}\right)$ is 0.001 . 
tion of plagioclase $38.74 \%$, hornblende $27.65 \%$, orthoclase $5.10 \%$, biotite $9.34 \%$, quartz $18.90 \%$ and apatite $0.26 \%$ with $0.00 \%$ residual liquid sample (S. No.18). The relatively small value $\sum \mathrm{R}^{2}(0.001)$ indicates a good fit of the resulting model.

\section{RARE EARTH ELEMENTS MODELING}

Rare earth elements modeling calculations have been used successfully in studying the petrogenesis and origin of basaltic rocks which may be derived by partial melting of upper mantle source materials.

The use of REE to explain the origin and evolution of igneous rocks is based on the use of $\mathrm{K}_{\mathrm{D}}$, (distribution coefficient), in quantitative models using partial melting and/or crystal fractionation.

Shaw (1970) modified a general equation for partial melting during batch melting in which the concentration of a given trace element in a melt $\left(C_{L}\right)$ relative to its concentration in the parent material $\left(\mathrm{C}_{\mathrm{o}}\right)$ is given by:

$$
\mathrm{C}_{\mathrm{L}} / \mathrm{C}_{\mathrm{o}}=1 /[\mathrm{D} \text { 。 }+\mathrm{F}(1-\mathrm{P})]
$$

By rearranging:

$$
=1 /\left[\left(D_{0}-P F\right)+F\right]
$$

where:

$$
\mathrm{D}_{\mathrm{o}}=\sum_{\mathrm{i}} \mathrm{X}^{\mathrm{i}} \mathrm{K}_{\mathrm{D}}{ }^{\mathrm{i}} \quad ; \mathrm{P}=\sum_{\mathrm{i}} \mathrm{p}^{\mathrm{i}} \mathrm{K}_{\mathrm{D}}{ }^{\mathrm{i}}
$$

$\mathrm{D}=$ The bulk distribution coefficient of the parent for a given rare earth element based on the mineral composition at the start of melting.

$\mathrm{X}^{\mathrm{i}}=$ The weight fraction of mineral $\mathrm{i}$ in the parent material.

$\mathrm{K}_{\mathrm{D}}{ }^{\mathrm{i}}=$ The mineral/melt distribution coefficient for a given rare earth element for mineral $i$.

$\mathrm{P}=$ The bulk distribution coefficient of the minerals making up the melt in which $\mathrm{P}^{\mathrm{i}}$ is the weight normative fraction of mineral $i$ in the melt.

$\mathrm{F}=$ The weight fraction of the melt relative to the original parent.

During differentiation, which is the evolution of a melt modified by fractional crystallization, the Rayleigh fractionation law, (Rayleigh, 1896), can be used to describe the trace element concentration of the differntiated melt, $\mathrm{C}_{\mathrm{L}}$, relative to the parent melt $\mathrm{C}_{\text {, }}$ (Neuman et al., 1954), as follows:

$$
\mathrm{C}_{\mathrm{L}} / \mathrm{C}_{\mathrm{o}}=\mathrm{F}^{(\mathrm{D}-1)}
$$

Where:

$$
\begin{aligned}
& \mathrm{F}=\text { fraction of the melt left } \\
& \mathrm{D}=\text { Bulk distribution coefficient of the crys- }
\end{aligned}
$$
tals settling out of the melt.

The calculations of the following models for the origin of the studied granitic rocks were carried out using the basic computer program (NEWPET, 1994) and the mineral/melt partition coefficient of the REE were taken from Arth (1976) for dacites and rhyolites quoted in Rollinson (1993), (Table 6).

The origin and evolution of igneous rocks using REE is based on $\mathrm{K}_{\mathrm{D}}$ (distribution coefficient) in quantitative models indicating differentiation and/or partial melting. The $\mathrm{K}_{\mathrm{D}}$ 's for a given element are dependent on the temperature and composition of the mineral and melt. Gast (1968) and Shaw (1970) suggested the theoretical derivations of quantitative modeling of trace elements for differentiation and partial melting of igneous rocks. Two models are commonly considered for partial melting: batch melting and fractional melting. In either model melting is assumed to occur under equilibrium conditions.

In the following models calculations, the average REE contents of the continental crust (Taylor and McLennan, 1985) were used as the parent materials involved in the generation of the studied granites. The continental crust is composed of $20 \mathrm{~km}$ upper granitic crust overlying $10 \mathrm{~km}$ dioritic middle crust above a $10 \mathrm{~km}$ gabbroic crust (Jackson et al., 1984).

\section{Petrogenesis of Gabal Delihimmi granites from the bulk continental crust source materials}

The studied granite of Gabal Delihimmi shows a REE pattern normalized chondrites using the values of Boynton (1984), (Fig.2a). The pattern reflects a fractionated magma enriched in LREE according to HREE with a small to moderate negative Eu anomaly. The average REE abundance pattern of Gabal Delhimmi is similar to that of the average of the bulk continental crust (Taylor and McLennan, 1985) so, it can be used 
CONTRIBUTIONS TO THE CHEMICAL MODELING

Table (6): Mineral/melt partition coefficients (KD) of REE for dacitic and rhyolitic melts, Arth (1976).

\begin{tabular}{|c|c|c|c|c|c|c|c|c|c|}
\hline Element & Pl & Hb. & Cpx & Bi & Qz & K-feld & Ilm & Zr & All \\
\hline $\mathrm{La}$ & 0.38 & - & 1.11 & 5.71 & 0.015 & 0.08 & 1.22 & 16.9 & 2594 \\
\hline $\mathrm{Ce}$ & 0.24 & .899 & 0.5 & 0.037 & 0.014 & 0.044 & 1.64 & 16.75 & 2278 \\
\hline $\mathrm{Nd}$ & 0.17 & 2.89 & 1.11 & 0.044 & 0.016 & 0.025 & 2.27 & 13.3 & 1620 \\
\hline $\mathrm{Sm}$ & 0.13 & 3.99 & 1.67 & 0.058 & 0.014 & 0.018 & 2.83 & 14.4 & 866.5 \\
\hline $\mathrm{Eu}$ & 2.11 & 3.44 & 1.56 & 0145 & 0.056 & 1.13 & 1.01 & 16 & 111 \\
\hline $\mathrm{Gd}$ & 0.9 & 5.48 & 1.85 & 0.082 & - & 0.011 & - & 12 & - \\
\hline $\mathrm{Dy}$ & 0.086 & 6.2 & 1.93 & 0.097 & 0.015 & 0.006 & 2.63 & 101.5 & 136.5 \\
\hline $\mathrm{Yb}$ & 0.077 & 4.89 & 1.58 & 0.179 & 0.017 & 0.012 & 1.47 & 257 & 30.8 \\
\hline $\mathrm{Lu}$ & 0.062 & 4.53 & 1.54 & 0.185 & 0.014 & 0.006 & 1.2 & 641.5 & 33 \\
\hline
\end{tabular}

$\mathbf{P l}=$ Plagioclase; $\mathbf{H b}=$ Hornblende; $\mathbf{C p x}=$ Clinopyroxene; $\mathbf{B i}=$ Biotite; $\mathbf{Q z}=\mathbf{Q u a r t z ; K - f e l d . = K - f e l d s p a r ;}$

Ilm=Ilmenite; $\mathbf{Z r}=$ Zircon and All=Allanite. as a source parent material. The modal mineral constituents of the source is: $60 \%$ plagioclase, $15 \%$ hornblende, $8 \%$ biotite, $5 \%$ quartz, $5 \%$ potash feldspar, $3 \%$ clinopyroxene and $2 \%$ ilmenite. At $40 \%$ degree of non-modal partial melting with major contribution of plagioclase and hornblende to the liquid composition followed by $35 \%$ crystal fractionation involving separation of biotite, $\mathrm{K}$-feldspar and quartz will give a best fit to the observed REE pattern of this type of granites as shown in (Fig. 2d), (Table 7). The calculated remaining source composition after $40 \%$ partial melting is: $60 \%$ plagioclase, $11.3 \%$ biotite; $9.6 \%$ hornblende, $6.3 \%$ potash-feldspar and quartz, $5 \%$ clinopyroxene, $1.3 \%$ ilmenite and $0.5 \%$ apatite.

\section{Petrogenesis of Gabal Um Shaddad granite from the upper continental crust source materials}

The studied younger granite of Gabal Um Shaddad shows a REE pattern normalized chondrites using the values of Boynton (1984), (Fig.2b). The pattern reflects a slightly flat fractionated magma enriched in LREE according to HREE with moderate negative Eu anomaly. The average REE abundance pattern of Gabal Um Shaddad is similar to that of the average of the upper continental crust (Taylor and Mclennan, 1985) so, it can be used as a source parent material. The suggested modal mineralogy of the source is: $45 \%$ potash feldspar, $40 \%$ quartz, $10 \%$ biotite and $5 \%$ plagioclase together with the REE abundance similar to the average of the upper continental crust (Taylor and McLennan, 1985). At 30\% degree of non-modal partial melting with major contribution of K-feldspar and quartz to the liquid composition followed

by $40 \%$ crystal fractionation involving separation of K-feldspar and quartz along with minor zircon will give a best fit to the observed REE pattern of this type of granites as shown in (Fig. 2e and Table 7). The calculated remaining source composition after $30 \%$ partial melting is: $45 \%$ $\mathrm{K}$-feldspar, $44.3 \%$ quartz, $5 \%$ plagioclase and $5.7 \%$ biotite.

\section{Petrogenesis of Gabal Abu Tiyur granites from the upper continental crust source materials}

It is worth to mention that the REE pattern of the studied granite of Gabal Abu Tiyur reflect two patterns (two types); the first exhibits more enriched LREE with more or less flat HREE and with small to moderate $\mathrm{Eu}$ anomaly, while the other type reflects smaller fractionated LREE than HREE with moderate to large Eu anomaly, (Fig.2c). Gabal Abu Tiyur (type 1) has average REE pattern similar to that of the average of the upper continental crust (Taylor and McLennan, 1985) so, it can be used as a source parent material. The suggested modal mineralogy of the source is: $45 \%$ potash feldspar, $40 \%$ quartz, $10 \%$ biotite and $5 \%$ plagioclase together with the REE abundance similar to the average of the upper continental crust (Taylor and McLennan, 1985). At 30\% degree of non-modal partial melting with major contribution of K-feldspar and quartz to the liquid composition followed by $40 \%$ crystal fractionation involving separation of K-feldspar and quartz along with minor zircon will give a best fit to the observed REE pattern of this type of granites as shown in (Fig.2e and Table 7). The calculated remaining source composition after $30 \%$ partial melting is: $45 \%$ $\mathrm{K}$-feldspar, $44.3 \%$ quartz, $5 \%$ plagioclase and $5.7 \%$ biotite. 
Gabal Abu Tiyur (type 2) has average REE pattern similar to that of the average of the upper continental crust (Taylor and McLennan, 1985) so, it can be used as a source parent material. The suggested modal mineralogy of the source is granitic in composition: $60 \%$ potash feldspar, $39.5 \%$ quartz and $0.5 \%$ apatite. After $50 \%$ degree of modal partial melting followed by $60 \%$ crystal fractionation involving separation of $\mathrm{K}$ feldspar and quartz along with minor allanite will give best fit to the observed REE pattern of this type of granites (Fig. 2f and Table 7).

1- Initial bulk continental crust concentration (Taylor and McLennan, 1985).

2- Initial upper continental crust concentration (Taylor and McLennan, 1985).

3- Liquid concentration resulted from $40 \%$ partial melting of bulk continental crust source.

4- Liquid concentration resulted from 35\% fractional crystallization to generate Delihimmi granites.

5- Liquid concentration resulted from $30 \%$ partial melting of upper continental crust source.

6- Liquid concentration resulted from $40 \%$ fractional crystallization to generate Um Shaddad and Abu Tiyur (type 1) granites.

7- Liquid concentration resulted from $50 \%$ partial melting of upper continental crust source.

8- Liquid concentration resulted from $60 \%$ fractional crystallization to generate Abu Tiyur (type 2) granite.
9- Average of studied Gabal Delihimmi granites.

10- Average of studied Gabal Um Shaddad granites.

11- Average of studied Gabal Abu Tiyur (type 1) granites.

12- Average of studied Gabal Abu Tiyur (type 2) granites.

\section{quantification of the tetrad effect}

Fidelis and Siekierski (1966) and Peppard et al. (1969) initially observed the tetrad effect in patterns of liquid-liquid REE distribution coefficients. Since then, the tetrad effect is well recognized in chemistry as affecting the REE complexing behaviour, which is assumed to be influenced by variations in the exchange interactions of unpaired $4 f$-electrons, spin orbit coupling or crystal field stabilization, (Mioduski, 1997). Masuda et al., (1987) proposed the existence of two different types of tetrad effects. Both types are derived from each other and mirror themselves by difinition (M-type in solid samples as residue and $\mathrm{W}$-type in the interacting fluids as extract). The labels "M" and "W" refer to REE patterns with upwards or downwards curved tetrads respectively.

Fractionation of minerals alone cannot explain non-CHARAC behavior of $\mathrm{Zr}$ and $\mathrm{Hf}, \mathrm{Y}$ and Ho (Bau, 1996 and 1997). Therefore, it is suggested that the tetrad effect and highly fractionated trace element ratios of $\mathrm{Y} / \mathrm{Ho}$ and $\mathrm{Zr} / \mathrm{Hf}$ indicate a trace element behavior that is simi-

Table (7): Initial and calculated concentrations (ppm) of REE resulted from partial melting and fractional crystallization processes for the studied granites.

\begin{tabular}{|c|c|c|c|c|c|c|c|c|c|c|c|c|}
\hline Element & 1 & 2 & 3 & 4 & 5 & 6 & 7 & 8 & 9 & 10 & 11 & 12 \\
\hline $\mathrm{La}$ & 16 & 30 & 16.5 & 9 & 52.5 & 84.8 & 53 & 38 & 41.7 & 88.8 & 126.8 & 32.6 \\
\hline $\mathrm{Ce}$ & 33 & 64 & 57.8 & 88 & 195 & 318 & 106 & 90 & 88.3 & 165 & 200 & 80.7 \\
\hline $\mathrm{Nd}$ & 16 & 26 & 23.4 & 35.5 & 81 & 133 & 39.8 & 46.4 & 35 & 96 & 131 & 45.7 \\
\hline $\mathrm{Sm}$ & 3.5 & 4.5 & 4.6 & 6.9 & 14 & 23.1 & 6.77 & 11 & 6.8 & 21 & 26.6 & 14.9 \\
\hline $\mathrm{Eu}$ & 1.1 & 0.88 & 0.75 & 0.97 & 1.17 & 1.3 & 0.95 & 1.1 & 1.15 & 3.13 & 4.49 & 0.86 \\
\hline $\mathrm{Gd}$ & 3.3 & 3.8 & 2.99 & 4.5 & 11.2 & 18.5 & 5.9 & 13.8 & 5.5 & 18.8 & 20.55 & 15.48 \\
\hline $\mathrm{Dy}$ & 3.7 & 3.5 & 4.2 & 6.3 & 11.2 & 18.1 & 5.5 & 12 & 5.9 & 19.5 & 18.1 & 19.7 \\
\hline $\mathrm{Yb}$ & 2.2 & 2.2 & 2.81 & 4.1 & 6.9 & 10.4 & 3.88 & 9.4 & 3.5 & 8.7 & 7 & 9.88 \\
\hline $\mathrm{Lu}$ & 0.3 & 0.32 & 0.4 & 0.6 & 1 & 1.4 & 0.58 & 1.4 & 0.6 & 1.2 & 1.06 & 1.42 \\
\hline
\end{tabular}



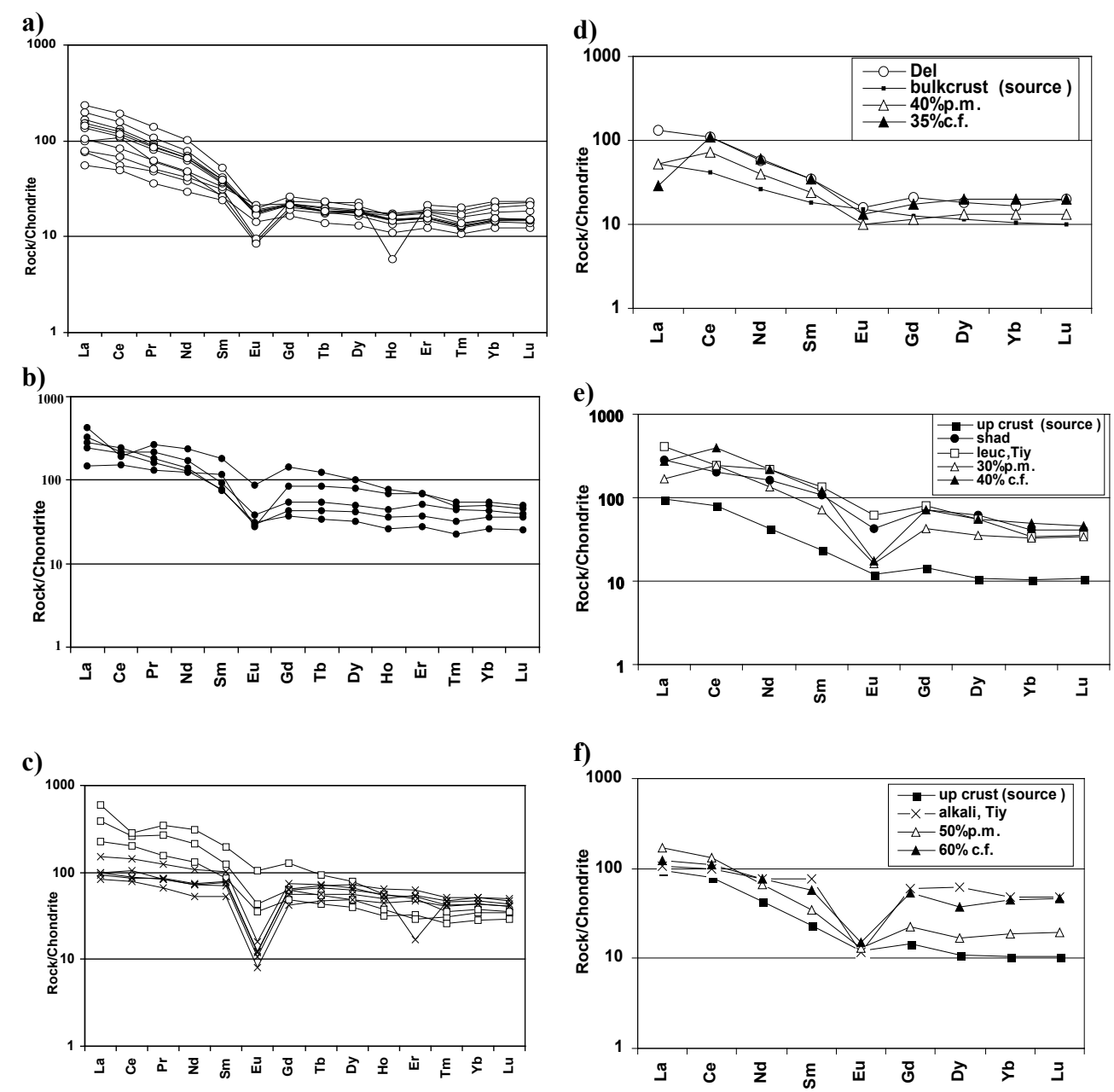

Fig.(2): a- Chondrite normalized REE pattern for Delihimmi granites.

b- Chondrite normalized REE pattern for Um Shaddad granites.

c- Chondrite normalized REE pattern for Abu Tiyur granites.

d- REE petrogenetic modeling for the generation of Gabal Delihimmi granites from bulk continental source materials.

e- REE petrogenetic modeling for the generation of Gabal Um Shaddad and Abu Tiyur (type 1) granites from upper continental source materials.

f- REE petrogenetic modeling for the generation of Gabal Abu Tiyur (type 2) granites from upper continental source materials.

lar to that in aqueous system in which chemical complexation is significant. The term 'tetrad effect' in geochemistry refers to the subdivision of the 15 lanthanide elements into four groups in a chondrite normalized distribution pattern: (1) $\mathrm{La}-\mathrm{Ce}-\mathrm{Pr}-\mathrm{Nd}$, (2) Pm-Sm-Eu- Gd, (3) TbDy-Ho, and (4) Er-Tm-Yb-Lu, and each group forms a smooth convex (M-type) or concave (Wtype) pattern (Masuda et al., 1987). The values of tetrad effect were calculated according to the quantification method of Irber (1999):

$$
\begin{aligned}
\mathrm{t} 1 & =(\mathrm{Ce} / \mathrm{Ce} * \times \mathrm{Pr} / \mathrm{Pr} *), \mathrm{t} 3=\left(\mathrm{Tb} / \mathrm{Tb}^{*} \times \mathrm{Dy} /\right. \\
\mathrm{Dy} *), \mathrm{t} 4 & =\left(\mathrm{Tm} / \mathrm{Tm} * \times \mathrm{Yb} / \mathrm{Yb}^{*}\right)
\end{aligned}
$$

Degree of the tetrad effect $\mathrm{T} 1,3=(\mathrm{t} 1 \times \mathrm{t} 3)^{0.5}$.

A REE pattern that does not show a tetrad effect has values of $\mathrm{TE}_{1.3}<1.1$. The M-shaped pattern shows TEi $>1.1$ and the W-shaped TEi< 0.9 .

The REE tetrad effect is most visible in late magmatic differentiates with strong hydrothermal interactions or deuteric alteration. This includes highly evolved leucogranites, pegmatites, and mineralized granites. Moreover, the tetrad effect is often accompanied by other modified geochemical behavior of many trace elements, which is termed by Bau (1996) as non-CHAR- 
AC behavior $(\mathrm{CHARAC}=$ Charge-and-RadiusControlled). Such behavior occurs typically in highly evolved magmatic systems enriched in $\mathrm{H}_{2} \mathrm{O}, \mathrm{CO}_{2}$ and elements such as $\mathrm{Li}, \mathrm{B}, \mathrm{F}$ and/or $\mathrm{Cl}$, which suggests the increasing importance of an aqueous like fluid system during the final stages of granite crystallization (Bau, 1996; Irber, 1999).

The kinked pattern, which is the characteristic REE tetrad effect, is well demonstrated in highly evolved granitic rocks. According to Masuda et al., (1987), extraction of a coexisting fluid from a peraluminous melt would result in both of the $\mathrm{M}$-shaped and W-shaped REE tetrad effect, the former of which would be shown in the residual melt phase and the latter of which shown in the fluid. However, this corresponding relationship for a magma system has not been observed in the natural environment. Recently, it has been argued that peraluminous magmatic systems represent the transition from a silicate melt to a hightemperature hydrothermal system, and thus, the geochemical behavior of the isovalent incompatible elements in highly evolved granitic rocks are controlled mainly by chemical complexation with a variety of ligands (Bau and Dulski, 1995; Bau, 1996, 1997; Dostal and Chatterjee, 2000). Therefore, the origin of the REE tetrad effect was ascribed to the interaction between fluorine bearing fluid and silicate melt phases (e.g., see Irber, 1999). Monecke et al., (2002) thought that the convex tetrad effect in the samples from the magmatic environment could not be explained by removal of a respective complementary REE pattern by a coexisting hydrothermal fluid, as they found that the fluorite samples collected from hydrothermal vein within the endocontact of the Li-F granite of Zinnwald, Germany, obviously have the M-shaped REE tetrad effect instead of the W-shaped tetrad effect. Therefore, they proposed that the tetrad effect might have formed within the magma fluid system before emplacement in the subvolcanic environment where phase separation caused a split of this system into fluid and magma subsystems, or that the tetrad effect might also be inherited from an external fluid influencing the system during or after the emplacement of the magma. Takahashi et al., (2002) recently found both W- and M-type tet- rad effect in REE patterns for the water-rock systems in the Tono uranium deposit, central Japan, which is interpreted as that the preference of the groundwater for a W-type tetrad effect produces an M-type tetrad effect in the granitic rocks during weathering processes. Cao et al., (2013) stated that, the tetrad effect observed in apatite from the muscovite granite and the pegmatite zones of Koktokay No. 3 pegmatite are most likely produced by the interaction of immiscible fluoride and silicate melts, rather than by weathering, fractional crystallization of individual mineral phases and/or fluid-melt interaction.

The tetrad effect in lanthanide patterns of whole-rock samples was quantified by equae tions 1, 2 and 3 proposed by Irber (1999). The calculated sizes $\mathrm{t} 1, \mathrm{t} 3$ and $\mathrm{t} 4$ of the tetrad effect of the studied granitic masses are listed in Table (8).

The kinks in the REE patterns are camouflaged by prominent convex and concave tetrads and pronounced negative $\mathrm{Eu}$ anomalies. Visual inspection suggests that the first tetrad in most samples is more prominent than the third and fourth curved segments. The second tetrad is comparably difficult to recognize due to the anomalous behavior of Eu and the fact that $\mathrm{Pm}$ does not occur in nature. Gabal Delihimmi granites have strong M-type tetrad effect of the first tetrad group in samples 2 and 11 and third group in sample 3 (Table 8). The index of tetrad effect intensity, T1,3 is higher than 1.10 for sample 3 of Gabal Delihimmi granites which implies that there was an interaction between melt and waterhaloid-rich fluid when these granites are crystallized from magma.

Gabal Um Shaddad granites show strong Wtype of the first and fourth groups in sample 14 (Table 8) which may indicate the effect of water enriched hydrothermal solutions on these granites. This assumption was also confirmed from the index of tetrad effect intensity T1,4 lesser than $9(\mathrm{TE} i<0.9)$.

With respect to Gabal Abu Tiyur type (1), sample 20 indicates the presence of strong Wtype tetrad from the first and fourth-types and M-type tetrad in sample 21 from the first type (Table 8). M-W- type tetrad effect in different 
samples may be related to the physico-chemical conditions that prevailed during the alteration processes and migration in and out of REEs in host and country rocks. In Abu Tiyur type (2), samples 22 and 24 were affected by strong Mtype tetrad from the fourth and first type respectively (Table 8) with pronounced index of tetrad effect intensity suggesting interaction between melt and water-haloid-rich fluid when these granites are crystallized from magma.

From the above mentioned tetrad effects the pattern is well demonstrated in highly differentiated rocks with strong hydrothermal interaction (Irber, 1999).

\section{Plot of the tetrad effect versus ratios of $K /$ $\mathbf{R b}, \mathrm{Sr} / \mathbf{E u}, \mathbf{E u} / \mathbf{E u}^{*}$ and $\mathrm{Y} / \mathrm{Ho}$}

The fractionation of elements which are similar to each other in terms of ionic radius and charge is regarded to be sensitive to changes in melt composition during magma differentiation (Bau, 1996). Therefore, the ratios of $\mathrm{K} / \mathrm{Rb}, \mathrm{Sr} /$ $\mathrm{Eu}, \mathrm{Eu} / \mathrm{Eu}^{*}$ and $\mathrm{Y} / \mathrm{Ho}$ are plotted against the tetrad effect to search for common underlying processes in trace element behaviour.

\section{$\mathbf{K} / \mathbf{R b}$}

In the studied granitic masses, the $\mathrm{K} / \mathrm{Rb}$ ratio ranges from 1.95 and 4.37 with an average of 3.57 for Gabal Delihimmi granite, while the ratio ranges from 4.01 and 4.84 with an average of 4.58 for Gabal Umm Shaddad granite. In Gabal Abu Tiyur granite (type 1 ) the $\mathrm{K} / \mathrm{Rb}$ ratio ranges from 6.81 to 7.85 with an average of 7.21, whereas in Gabal Abu Tiyur granite (type 2) it ranges from 3.39 to 7.12 with an average of 4.23 (Table 8 ). The tetrad effect negatively correlates with $\mathrm{K} / \mathrm{Rb}$ (Fig.3.a) and most of the studied samples show significant tetrad effects $(\mathrm{T}>1)$. The chondritic $\mathrm{K} / \mathrm{Rb}$ ratio is 242 (Anders and Grevesse, 1989) and the average of the magmatic rocks is given as 230 with most of the crustal rocks ranging from 150 to 350 (Taylor, 1965). With increasing degree of differentiation, $\mathrm{Rb}$ fractionates preferentially into the residual melt and the $\mathrm{K} / \mathrm{Rb}$ ratios decrease in highly evolved magmatic systems below 50 (Irber, 1999).

\section{$\mathrm{Sr} / \mathrm{Eu}$ and $\mathbf{E u} / \mathrm{Eu}^{*}$}

The $\mathrm{Sr}$ and Eu display a distinctive behaviour during magma evolution and bear information relevant to trace element behaviour in general. The samples in this study range in $\mathrm{Sr} / \mathrm{Eu}$ from 2.96 to 154.03 (Table 8). The majority of Gabal Delihimmi granites ratios is close to the chondritic value of 139 (Anders and Grevesse, 1989). $\mathrm{Eu}$ is somewhat increased in the residual melt and can be enriched with respect to $\mathrm{Sr}$ during granite differentiation (decreasing in $\mathrm{Sr} / \mathrm{Eu}$ ratio). The calculated ratios of $\mathrm{Sr} / \mathrm{Eu}$ show relative increasing trend with the tetrad effect (Fig.3.b) due to the decrease in Eu concentration as a result of negative Eu anomalies.

When plotting the $\mathrm{Eu} / \mathrm{Eu}^{*}$ ratios against the tetrad effect (Fig.3.c), they show relative decrease between the tetrad effect and the size of $\mathrm{Eu}$ anomalies in the studied granitic masses.

\section{Y/Ho}

The chondritic ratio of $\mathrm{Y} / \mathrm{Ho}$ is 28 (Anders and Grevesse, 1989), and the ratios range from 20.16 to 31.27 in the studied granites except one sample of Gabal Delihimmi granite which reaches 106.34 (Table 8). Paralleled by the increasing degree of the tetrad effect the ratios shift to values $>28$ (Fig.3.d). Bau and Dulski (1995) suggest the complexation with fluorine as major cause for values $>28$, while the complexing with bicarbonate is assumed to generate values $<28$.

The REE tetrad effect was mainly observed in late magmatic differentiation related to strong hydrothermal interactions or deuteric alteration, Dupuy et al., (1992). The high-temperature alteration indicated by REE pattern displaying the tetrad effect albitization resulted from fluid-rock interaction.

\section{SUMMARY AND CONCLUSION}

From the previous results and discussions, the following can be concluded:

1- Gabal Delihimmi $\left(140 \mathrm{~km}^{2}\right)$, Gabal Abu Tiyur $\left(30 \mathrm{~km}^{2}\right)$ and Gabal Um Shaddad $\left(17 \mathrm{~km}^{2}\right)$ are three granitic masses intruded into older metavolcanics and metasediments located in the Central Eastern Desert.

2- The modal mineralogic analysis shows that Gabal Delihimmi granites are composed of orthoclase perthites, quartz, plagioclase and 
Table (8): The tetrad effect values and some elemental ratios calculations of the studied granitic masses.

\begin{tabular}{|c|c|c|c|c|c|c|c|c|c|}
\hline S. No. & t1 & t3 & t4 & T1,3 & $\mathrm{T} 1,4$ & $\mathbf{K} / \mathbf{R b}$ & Sr/Eu & Eu/Eu* & Y/Ho \\
\hline 1 & 0.988 & 0.979 & 0.985 & 0.984 & 0.987 & 2.23 & 140.76 & 11.33 & 20.16 \\
\hline 2 & 1.209 & 0.993 & 0.956 & 1.096 & 1.075 & 3.89 & 118.06 & 12.80 & 28.10 \\
\hline 3 & 1.058 & 1.930 & 1.007 & 1.429 & 1.032 & 2.37 & 167.68 & 12.43 & 106.34 \\
\hline 4 & 1.044 & 0.989 & 0.963 & 1.016 & 1.003 & 4.37 & 81.21 & 18.31 & 28.68 \\
\hline 5 & 1.059 & 0.977 & 0.964 & 1.017 & 1.011 & 1.95 & 154.03 & 10.72 & 31.27 \\
\hline 6 & 1.065 & 1.012 & 0.957 & 1.038 & 1.010 & 3.98 & 71.50 & 16.55 & 30.00 \\
\hline 7 & 1.052 & 1.009 & 0.963 & 1.030 & 1.007 & 3.82 & 81.37 & 17.29 & 28.99 \\
\hline 8 & 1.074 & 1.008 & 0.945 & 1.040 & 1.008 & 4.28 & 78.07 & 16.66 & 28.86 \\
\hline 9 & 1.060 & $\mathbf{0 . 9 9 7}$ & 0.940 & 1.028 & 0.998 & 4.07 & 80.23 & 16.57 & 28.30 \\
\hline 10 & 1.067 & 1.013 & 0.937 & 1.040 & 1.000 & 4.21 & 83.66 & 16.07 & 28.94 \\
\hline 11 & 1.136 & 1.040 & $\mathbf{0 . 9 3 7}$ & 1.028 & 1.007 & 4.05 & 78.89 & 19.16 & 28.22 \\
\hline Av. & 1.074 & 1.086 & 1.071 & 1.068 & 1.013 & 3.57 & 103.22 & 15.26 & 35.26 \\
\hline 12 & 0.948 & 1.045 & 0.973 & 0.995 & 0.998 & 4.84 & 16.71 & 38.73 & 30.13 \\
\hline 14 & 0.728 & 1.043 & 0.817 & 0.918 & 0.871 & 4.23 & 8.21 & 93.87 & 24.39 \\
\hline 15 & 1.074 & 1.048 & 1.010 & 1.061 & 0.951 & 4.98 & 24.10 & 28.66 & 27.61 \\
\hline 16 & 1.086 & 1.053 & 1.025 & 1.069 & 0.967 & 4.01 & 3.43 & 43.13 & 25.71 \\
\hline 17 & 1.078 & 1.066 & 1.016 & 1.072 & 0.957 & 4.83 & 22.35 & 31.08 & 28.19 \\
\hline Av. & 0.983 & 1.051 & 1.014 & 1.023 & 0.949 & 4.58 & 14.96 & 47.09 & 27.21 \\
\hline 18 & 1.052 & 1.046 & 0.918 & 1.049 & 0.982 & 6.81 & 8.46 & 34.82 & 24.98 \\
\hline 19 & 0.920 & 1.061 & 1.058 & 0.988 & 0.987 & 7.85 & 5.77 & 43.78 & 27.51 \\
\hline 20 & 0.752 & 1.005 & 0.889 & $\mathbf{0 . 8 7 0}$ & 0.818 & 6.96 & 2.96 & 97.58 & 24.44 \\
\hline Av. & 0.908 & 1.037 & 0.969 & 0.969 & 0.929 & 7.21 & 5.73 & 58.73 & 25.64 \\
\hline 21 & 1.119 & 1.090 & 0.985 & 1.105 & 1.050 & 7.12 & 10.17 & 15.52 & 27.59 \\
\hline 22 & 1.053 & 1.071 & 1.775 & 1.062 & 1.367 & 3.70 & 4.29 & 23.49 & 26.84 \\
\hline 23 & 1.036 & 1.056 & 0.973 & 1.046 & 1.004 & 3.44 & 9.22 & 20.34 & 30.42 \\
\hline 24 & 1.131 & 1.101 & 0.965 & 1.116 & 1.045 & 3.39 & 4.89 & 23.51 & 28.15 \\
\hline 25 & 1.071 & 1.084 & 0.953 & 1.077 & 1.011 & 3.52 & 7.67 & 28.86 & 27.96 \\
\hline Av. & 1.082 & 1.080 & 1.081 & 1.081 & 1.095 & 4.23 & 7.25 & 22.34 & 28.19 \\
\hline
\end{tabular}
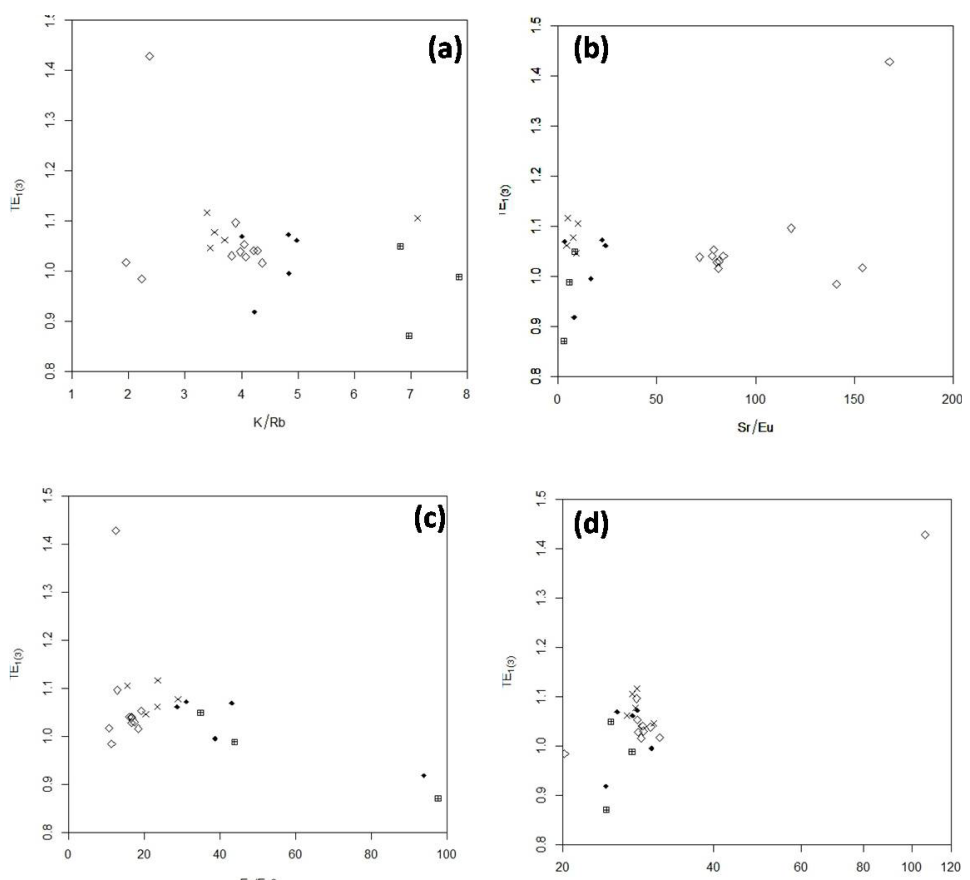

Fig.(3): Tetrad versuS K/Rb, $\mathrm{Sr} / \mathrm{Eu}, \mathrm{Eu} / \mathrm{Eu} *$ and $\mathrm{Y} / \mathrm{Ho}$ in the studied granitic masses (Symbols as in Fig.2). 
biotites whereas Gabal Abu Tiyur and Gabal Um Shaddad granites are composed of microcline perthites, quartz, plagioclase and minor biotites.

3- Fractional crystallization and mass balance modeling for the younger granites of Gabal Delihimmi, Gabal Um Shaddad and Gabal Abu Tiyur indicate their derivation from the parent mafic magma granodiorite.

4- Rare earth elements petrogenetic modeling indicates that Gabal Delihimmi granite can be produced by $40 \%$ non-modal partial melting of bulk continental source materials followed by $35 \%$ crystal fractionation. Gabal Abu Tiyur granite (type 1) and Gabal Um Shaddad granite can be produced by $30 \%$ non-modal partial melting of upper Continental source materials followed by $40 \%$ crystal fractionation. On the other hand, the granite of Abu Tiyur (type 2) can be produced from granite source materials by $50 \%$ partial melting followed by $60 \%$ crystal fractionation.

5- The correlation of tetrad effect with ratios of $\mathrm{K} / \mathrm{Rb}, \mathrm{Sr} / \mathrm{Eu}, \mathrm{Eu} / \mathrm{Eu}^{*}$ and $\mathrm{Y} / \mathrm{Ho}$ proves that the tetrad effect develops parallel to granite differentiation, and significant tetrad effect are clearly restricted to the more highly differentiated granite samples.

6- The tetrad effect was a feature of the magma-fluid system before magmatic crystallization or that the tetrad effect in the whole rock samples was inherited from an external fluid during or after the emplacement of the magma.

\section{ACKNOWLEDGEMENT}

The author would like to express his deep gratitude to the Late Prof. Ewais M.M. Moussa, Dr. Hassan A. Shahin and Prof. Mohamed G. ElFeky of NMA for their endless help.

\section{REFERENCES}

Abd El-Wahed, A.A., Ammar, S.E., Youssief, T.F. and El-Husseiny, M.O., 2002, Petrography, REE geochemistry and $\mathrm{Rb}-\mathrm{Sr}$ isotopes study of Abu Tiyur granite, Central Eastern Desert, Egypt. M.E.R.C., Ain Shams Univ., Earth Sci. Ser., 16, 16-24.

Abd El-Wahed, A.A., El-Aassy, I.E., Ragab, A.I., Ammar, S.E. and El-Husseiny, M.O., 2004: The proterozoic magmatism in El-Delihimmi area, Central Eastern Desert, Egypt: Geochemical approach. The $6^{\text {th }}$ Intern. Conf. on Geochem., Alex. Univ., Egypt, 183-197.
Albaréde, F., 1995, Introduction to Geochemical Modeling. Cambridge University Press, Cambridge, 543p.

Anders, E. and Grevesse, N., 1989: Abundances of the elements: Meteoritic and solar. Geochem. Cosmochem. Acta, 53, 197-214.

Arth, J.G., 1976: Behavior of trace elements during magmatic processes: A summary of theoretical models and their application. Jour. Res. U.S. Geol. Surv., 4, 41-47.

Bau, M., 1996: Controls on the fractionation of isovalent trace elements in magmatic and aqueous systems: evidence from $\mathrm{Y} / \mathrm{Ho}, \mathrm{Zr} / \mathrm{Hf}$ and lanthanide tetrad effect. Contrib. Mineral. Petrol., 123, 323-333.

Bau, M., 1997: The lanthanide tetrad effect in highly evolved felsic igneous rocks: A reply to the comment by Y. Pan. Contrib. Mineral. Petrol., 128, 409-412.

Bau, M. and Duloski, P., 1995: Comparative study of yttrium and rare earth element behaviours in fluorine-rich hydrothermal fluids. Contrib. Mineral. Petrol., 119, 213-223.

Cao, M., Zhou, Q., Qin, K.Z., Tang, D.M. and Evans, N.J., 2013, The tetrad effect and geochemistry of apatite from the Altay Koktokay No.3 pegmatite, Xinjiang, China: Implications for pegmatite petrogenesis. Mineral. Petrol., 107, 985-1005.

Deer, W.A., Howie, R.A. and Zussman, J., 1966, An Introduction to The Rock Forming Minerals. Longman, London, 528p.

Dostal, J. and Chatterjee, A.K., 2000, Contrasting behaviour of $\mathrm{Nb} / \mathrm{Ta}$ and $\mathrm{Zr} / \mathrm{Hf}$ ratios in a peraluminous granitic pluton (Nova Scotia, Canada). Chem. Geol., 163, 207-218.

Dupuy, C., Liotard, J.M. and Dostal. J., 1992: Zr/Hf fractionation in intraplate basaltic rocks: Carbonate metasomatism in the mantle source. Geochem. Cosmochem. Acta, 56, 2417-2423.

El-Alfy, Z., 1992: Geological studies on the area north of Gabal Abu Tiyur, Central Eastern Desert, Egypt. Ph.D. Thesis, Fac. Sci., Ain Shams Univ., Egypt, 177p.

El-Gaby, S., List, F.K. and Tehrany, R., 1988: Geology, evolution and metallogenesis of Pan-African belt in Egypt. In: El Gaby, S. and Greilling, R.O., (eds). The Pan-African belt of North-East Africa and adjacent areas, tectonic evolution and economic aspects of late Proterozoic orogen; Fried Vieweg and Sohn, Braunshweig/Wiesbaden, 17-67.

El-Husseiny, M.O., 2003: Geology, geochemistry and distribution of uranium and thorium in Gabal Nusla area, Central Eastern Desert, Egypt. Ph.D. Thesis, Fac. Sci., Ain Shams Univ., Egypt, 171p.

Fidelis, I. and Siekierski, S., 1966: The regularities in stability constants of some rare earth complexes. Jour. Inorg. Nucl. Chem., 28, 185-188.

Gast, P.W., 1968: Trace element fractionation and the 
origin of tholeiitic and alkaline magma types. Geochim. Cosmochim. Acta, 32, 1057-1086.

Hamimi, Z., 1996: Tectonic evolution of the shield rocks of Gabal El-Sebai area, Central Eastern Desert, Egypt. Egy. Jour. Geol., 40 (1), 423-453.

Hassan, M.A. and Hashad, A.H., 1990: Precambrian of Egypt. In: Said R. (ed.), Geology of Egypt. Bulkema Publ., The Netherlands, 734p.

Hussein, A.A., Ali, M.M. and El Ramly, M.F., 1982: A proposed new classification of the granites of Egypt. Jour. Volcan. Geother. Res., 14, 187-198.

Irber, W., 1999: The lanthanide tetrad effect and its correlation with $\mathrm{K} / \mathrm{Rb}, \mathrm{Eu} / \mathrm{Eu}$ * $\mathrm{Sr} / \mathrm{Eu}, \mathrm{Y} / \mathrm{Ho}$ and $\mathrm{Zr} / \mathrm{Hf}$ of evolving peraluminous granite suites. Geochem. Cosmochem. Acta, 63 (3/4), 489-508.

Jackson, N.J., Walsh, J.N. and Pegram, E. 1984: Geology, geochemistry and petrogenesis of late Precambrian granitoids in the Central Hijaz region of the Arabian Shield. Contrib. Mineral. Petrol., 87, 205-219.

Khudeir, A.A., El-Gaby, S., Kamal El Din, G.M., Asran, H.A. and Greiling, R.B., 1995: The pre Pan-African deformed granite cycle of the Gabal El-Sebai swell, Eastern Desert, Egypt. Jour. Afr. Earth Sci., 21 (3), 395-406.

Masuda, A., Kawakami, O., Dohomoto, Y. and Takenaka, T., 1987: Lanthanide tetrad effects in nature: Two mutually opposite types W and M. Geochem. Jour., 21, 119-124.

Mioduski, T., 1997: The 'regular' and 'inverse' tetrad effect. Comments Inorg. Chem., 19, 93-119.

Mohamed, M.A., 2001: Geology, petrology and radioactivity of Gabal El-Sebai area, Central Eastern Desert, Egypt. Ph.D. Thesis, Fac. Sci., Cairo Univ., Egypt, $300 \mathrm{p}$.

Mohamed, F.H., El-Sayed, M.M., Furnes, H. and Kanisawa, S., 2001: Geochemistry and petrogenetic aspects of the Neoproterozoic plutonic rock suites in the Umm Gheig province, Central eastern Desert, Egypt: Special emphasis on the granitic rock suites. The $5^{\text {th }}$ Intern. Conf. on Geochem., Alex. Univ., Egypt, Abst., 79-80.

Monecke, T., Kempe, U., Monecke, J., Sala, M. and Wolf, D., 2002: Tetrad effect in rare earth element distribution patterns: A method of quantification with application to rock and mineral samples from graniterelated rare metal deposits. Geochim. Cosmochim. Acta, 66 (7), 1185-1196.

Neuman, H., Mead, J. and Vitalino, G.J., 1954: Trace element variations during fractional crystallization as calculated from the distribution law. Geochim. Cosmochim. Acta, 6, 90-99.

Newpet, 1994: Basic program, D. Clarke, Memorial Uni. Newfoundland, Earth Sci. Dept., Canada.

Peppard, D.F., Mason, G.W. and Lewely, S., 1969: A tetrad effect in liquid-liquid extraction ordering of lanthanides (III). Jour. Inorg. Nucl. Chem., 31, 2271-2272.

Ragab, A.I., El-Kalioubi, B.A. and El-Alfy, Z., 1993: Petrotectonic assemblages and crustal evolution of the area north of Abu El-Tiyur, Central Eastern Desert, Egypt, M.E.R.C. Ain Shams Univ., Earth Sci. Ser., 7, $1-16$.

Rayleigh, J.W.S., 1896: Theoretical considerations respecting the separation of gases by diffusion and similar processes. Philos. Mag., 42-77.

Ries, A.C., Shackelton, R.M., Graham, R.H. and Fitches, W.R., 1983: Pan-African structures, ophiolites and melange in the Eastern Desert of Egypt, a traverse at $26^{\circ}$ N. Jour. Geol. Soc. London, 140, 75-95.

Rollinson, H., 1993: Using geochemical data: evaluation, presentation, interpretation. Longman, John Wiley \& Sons Inc., New York.

Sabet, A.H., 1961: Geology and mineral deposits of Gebel El-Sebai area, Red Sea Hills, Egypt. Ph.D. Thesis, Leiden State Univ., The Netherlands, 200p.

Shaw, D.M., 1970: Trace element fractionation during anatexis. Geochim. Cosmochim. Acta, 34, 237-243.

Taylor, S.R., 1965, The application of trace elements data to problems in petrology. Phys. Chem. Earth, 6, 133213.

Taylor, S.R. and McLennan, S.M., 1985: The continental crust: its composition and evolution. Blackwell Scientific Publications, 312p.

Wright, T.L. and Doherty, P.C., 1970, A linear programming and least square computer method for solving petrologic mixing problems. Geol. Soc. Am. Bull., 81, 1995-2008. 